\title{
Trophic niche partitioning in marine wood-borers revealed by stable isotope analysis
}

\author{
François Charles ${ }^{1, *}$, Pascal Riera ${ }^{2}$, Pierre-Guy Sauriau ${ }^{3}$, François Lantoine ${ }^{1}$, \\ Benoît Lebreton $^{3}$, Hélène Agogué ${ }^{3}$, Stéphane Hourdez ${ }^{1}$ \\ ${ }^{1}$ Sorbonne Université, CNRS, Laboratoire d'Ecogéochimie des Environnements Benthiques, UMR 8222 LECOB, \\ Observatoire Océanologique, 66650 Banyuls-sur-Mer, France \\ ${ }^{2}$ Sorbonne Université, CNRS, Adaptation et diversité du milieu marin, UMR7144 AD2M, Station Biologique de Roscoff, \\ 29680 Roscoff, France \\ ${ }^{3}$ Université de La Rochelle, CNRS, Littoral Environnement et Sociétés, UMR 7266 LIENSs, 2 rue Olympe de Gouges, \\ 17000 La Rochelle, France
}

\begin{abstract}
Marine wood-borers often live in sympatry, sharing deadwood scattered at sea, both as food and habitat. In this study, carbon and nitrogen isotope compositions were determined to test the hypothesis that the trophic niches of Chelura terebrans, Limnoria quadripunctata, and Nototeredo norvagica obtained from softwood boards maintained in running, unfiltered seawater are different. Comparison of isotope compositions supports niche partitioning, with $N$. norvagica foraging primarily on wood, and crustaceans foraging on decaying wood. Needs and acquisition routes for nitrogen determine the trophic behavior of the species. Results presented here are valuable for assessing the impact of wood-boring species on each other, but also for evaluating the effect of the separation of carbon and nitrogen sources on the diversity of the interactions between co-existing species belonging to the same trophic guild.
\end{abstract}

KEY WORDS: Co-occurring marine wood-eaters - Trophic ecology $\cdot$ Stable isotopes $\cdot$ In situ experiment $\cdot$ Mediterranean Sea

\section{INTRODUCTION}

Since the Devonian, a large amount of wood produced on land has been entering the sea, where some consumers are specialized to use this organic matter with great efficiency. Marine wood-borers have the ability to depolymerize lignocellulose and metabolize plant polysaccharides. They are also attractive biological models for studying ecology at metacommunity levels as species come together around a food resource that is allochthonous, rare, ephemeral, and fragmented (MacIntosh et al. 2012).

In shallow environments, communities depending on large woody debris consist mainly of the amphipods from the family Cheluridae (Barnard 1959), nearly all the representatives of the Teredinidae bivalve family

${ }^{*}$ Corresponding author: francois.charles@obs-banyuls.fr
(Distel et al. 2017, Velásquez \& Shipway 2018), and most isopods of the family Limnoriidae (Cragg et al. 1999, Cookson et al. 2012). Species belonging to these 3 taxonomic groups often live in sympatry, using deadwood scattered at sea both as food source and habitat (Björdal \& Nilsson 2008, Cragg et al. 2009, Heise et al. 2011, Borges \& Costa 2014, Borges et al. 2014a,b, Nishimoto et al. 2015). Large-size worm-like bivalves, better known as shipworms, dig burrows deep into wood (Turner 1966), small-size limnoriids dig tunnels right below the surface of the wood (Menzies 1952), while chelurid amphipods only produce superficial furrows or widen existing limnoriid tunnels (Barnard 1955). Such differences of behaviors suggest that the co-occurring wood-consumers do not compete for, but rather share the resource.

() The authors 2020. Open Access under Creative Commons by Attribution Licence. Use, distribution and reproduction are unrestricted. Authors and original publication must be credited. 
Wood is a natural composite (Levasseur et al. 2013, Chen 2014, Westereng et al. 2015) in which cellulose must be seen as the reinforcement and hemicelluloses and lignin as the concrete in which the reinforcement is embedded. Cellulose consists of long linear chains of D-glucose monomers, held together by strong hydrogen bonds to form microfibrils, a highly ordered crystalline structure difficult to depolymerize. Unlike cellulose, hemicelluloses are short branched polysaccharides of 5and 6-carbon sugar monomers that interact with lignin and bind cellulose microfibrils together to produce the cross-linked wood fiber texture (Terrett \& Dupree 2019). On top of that, the 3-dimensional phenolic nature of lignin, devoid of defined chemical primary structure, acts as a barrier hindering the action of enzymes on the polysaccharides. The conversion of cellulose into biomass thus implies that consumers manage the mechanical breakdown of wood and the hydrolysis of its constituents. Either rasped by toothed ridges of shells or torn by mandibles, wood fragments are digested by a large number of enzymes that act sequentially and synergistically to complete cellulose saccharification. Typically, lignin-modifying enzymes, mainly peroxidase and phenol oxidase-like enzymes, first induce lignin disruptions allowing cellulases to access their substrates (Coll et al. 1993, Sinsabaugh 2010, Janusz et al. 2017, Bredon et al. 2019). Then, lytic polysaccharide monooxygenase (LPMO) enzymes perform oxidative cleavages directly on crystalline cellulose (Vaaje-Kolstad et al. 2010). The induction of chain breaks by LPMOs boosts the activity of the classical glycoside hydrolase $(\mathrm{GH})$ families (Eibinger et al. 2014), that are only able to productively bind single polysaccharide chains (Westereng et al. 2015).

In the total or nearly total absence of a gut-resident microbiota (Boyle \& Mitchell 1978, Betcher et al. 2012), marine wood consumers are able to secrete cellulases and peroxidase-like compounds endogenously (King et al. 2010). However, the sets of enzymes involved in the depolymerization and digestion of the plant cell walls differ between the long vermiform bivalves and the small crustacean wood-borers (Besser et al. 2018, Sabbadin et al. 2018). The mollusks stand out even more from the crustaceans by a complex cocktail of endogenous and symbiotic enzymes (O'Connor et al. 2014, Sabbadin et al. 2018). In this context, lignocellulose is probably not digested with the same efficiency by consumers. Besides, ${ }^{13} \mathrm{C}$ enrichment of the consumers can be expected due to absence of digestion of the relatively ${ }^{13} \mathrm{C}$-depleted lignin as compared to the more labile polysaccharides or to the whole plant (Benner et al. 1991). Wood is a very poor source of nitrogen (Delwiche et al. 1979, Lamlom \& Savidge 2003). In teredinids, endosymbiotic bacteria provide a significant amount of nitrogen to their host through $\mathrm{N}_{2}$ fixation (Lechene et al. 2007, Charles et al. 2018a). In contrast, limnoriids and amphipods must rely on their food to fulfill their nitrogen needs. With the sources being different, different isotope compositions of nitrogen between the mollusks and the arthropods should also be expected. To test these hypotheses, the aim of the present study was to use stable isotopes to investigate carbon and nitrogen source partitioning. Based on the isotopic differences between the main molecular components of plants (Benner et al. 1987, 1991), on the enzymatic potencies of the consumers (Cragg et al. 2015), and on the diversity of nitrogen acquisition pathways (Daniel et al. 1991, Lechene et al. 2007, Charles et al. 2018a), we expected that a combination of $\delta^{13} \mathrm{C}$ and $\delta^{15} \mathrm{~N}$ values would elucidate the trophic niches of the cooccurring wood-borers.

\section{MATERIALS AND METHODS}

\subsection{Experimental design}

The experiment was performed in 2016 at the Laboratoire Arago of Banyuls-sur-Mer, northwest Mediterranean Sea, France. A dozen small boards $(200 \times$ $70 \times 15 \mathrm{~mm}$, longitudinal $\times$ tangential $\times$ radial axes) were manufactured from commercially available untreated and unplaned planks of spruce wood Picea abies. The volumetric mass density of the wood was about $450 \mathrm{~kg} \mathrm{~m}^{-3}$. Six boards were deployed on March 17 in a polycarbonate aquarium $600 \times 400 \times$ $200 \mathrm{~mm}$ (length $\times$ width $\times$ height) supplied with running, unfiltered seawater pumped from the bay. Circulation of seawater through the aquarium was maintained at a rate of about 3-3.55 $1 \mathrm{~min}^{-1}$. Exposure ended on October 24, 2016. Yücel et al. (2013) have shown that under such conditions, propagules and juveniles of wood-borers could enter experimental aquaria through the seawater pumping circuit.

\subsection{Sampling and preparation for stable isotope analyses}

Carbon and nitrogen isotope compositions of particulate organic matter suspended in the seawater 
(SPOM) were analyzed on 4 occasions: June 9, July 11, September 12, and October 24. Water samples were collected near the water pumping site and pre-filtered through a $200 \mu \mathrm{m}$ mesh to remove large zooplankton and detritus. SPOM was then recovered by filtration on pre-combusted Whatman GF/F filters, $25 \mathrm{~mm}$ in diameter, $0.7 \mu \mathrm{m}$ pore size. The filters were then placed into individual Petri dishes and dried in an oven at $50^{\circ} \mathrm{C}$ overnight. Dry filters were kept away from light in a desiccator until analysis.

Isotope compositions of the experimental spruce wood boards were analyzed at the time of deployment (i.e. March) and at the end of the experiment. Animals present inside the wood boards were sampled at the end of the experiment.

Isopods and amphipods were collected using fine tweezers and grouped into batches of several individuals (20 to 60) to get sufficient sample mass material for running duplicate stable isotope measurements. Thereafter, wood boards were cut with a chisel for the collection of shipworms and wood samples. Wood chips were collected on the outer edges and in the inner part of the wood boards. All the sampled animals present were kept alive for $24 \mathrm{~h}$ in filtered seawater (Whatman GF/F) to allow evacuation of the gut contents, and shipworms were then dissected to separate flesh from the shells and pallets (a pair of small paddle-like calcareous plates that seal the opening of the burrow when the siphons are retracted). For species identification, we used the illustrated catalogue of Teredinidae by Turner (1966), the key to European Limnoria species by Castelló (2011), and the monograph of Mediterranean amphipods by Bellan-Santini et al. (1982). Wood chips and animal tissues were briefly rinsed with deionized water and stored in aluminum foil at $-20^{\circ} \mathrm{C}$ until further analysis. All animal and wood samples were freezedried and then ground into a fine powder using a ball mill (MM 400, Retsch) and a sander (R3000, Dremel), respectively. Samples were then weighed into tin capsules (ca. 0.3 to $0.4 \mathrm{mg}$ for animal tissues and carbon analysis of wood, and ca. 4 to $5 \mathrm{mg}$ for nitrogen analysis of wood).

Samples used for the measurement of $\delta^{13} \mathrm{C}$ values were acidified prior to analysis to remove inorganic carbon, as carbonates from the exoskeletons of animals and algae are more enriched in ${ }^{13} \mathrm{C}$ than the organic carbon issued from the food resources (Søreide et al. 2006). A subsample of powder or the first half of each filter was acidified for $4 \mathrm{~h}$ under $37 \%$ $\mathrm{HCl}$ vapors (Malet et al. 2008). A second subsample of powder and the other half of the filters were analyzed without any pre-treatment for determination of $\delta^{15} \mathrm{~N}$ values (Bunn et al. 1995, Kennedy et al. 2005). The 2 sets of subsamples (i.e. acidified and non-acidified) were packed separately into individual tin capsules.

\subsection{Measurement of stable isotope compositions}

Carbon and nitrogen isotope compositions were determined using an elemental analyzer (Flash EA 1112, Thermo Scientific) coupled to a continuousflow isotope-ratio mass spectrometer (Delta V Plus with a Conflo IV interface, Thermo Scientific). Analyses were conducted at the LIENSs stable isotope facility at the University of La Rochelle, France. Data are expressed in $\delta$ notation (in \%o) as deviations from international standards (Vienna Pee Dee Belemnite for $\delta^{13} \mathrm{C}$ and $\mathrm{N}_{2}$ in air for $\delta^{15} \mathrm{~N}$ ), following the formula: $\delta^{13} \mathrm{C}$ or $\delta^{15} \mathrm{~N}=\left[\left(\mathrm{R}_{\text {sample }}{ }^{\prime}\right.\right.$ $\mathrm{R}_{\text {reference }}$ ) - 1] $\times 1000$, where $\mathrm{R}$ is ${ }^{13} \mathrm{C} /{ }^{12} \mathrm{C}$ for carbon and ${ }^{15} \mathrm{~N} /{ }^{14} \mathrm{~N}$ for nitrogen, respectively. Calibration was done using reference materials (USGS24, IAEA-CH6, IAEA-600, USGS-61, and USGS-62 for carbon; IAEA-N2, IAEA-NO-3, IAEA-600, USGS61, and USGS-62 for nitrogen). Analytical precision was $<0.15 \%$ for both $\mathrm{C}$ and $\mathrm{N}$ based on the analyses of acetanilide (Thermo Scientific) and peptone (Sigma-Aldrich) used as internal laboratory standards.

\subsection{Data analysis and statistical treatment}

Wood from the outer edge and the inner part of the boards were considered separately, with SPOM, as potential food sources. Dissolved $\mathrm{N}_{2}$ was considered an additional potential source. We used the $\delta^{15} \mathrm{~N}$ value of $0.6 \%$ published by Sigman et al. (2009).

All statistics were performed using $\mathrm{R}$ ( $\mathrm{R}$ Core Team 2018). Kruskal-Wallis tests were used to compare the $\delta$ values and $\mathrm{C} / \mathrm{N}$ ratios among sources (i.e. outer wood, inner wood, and SPOM) and among consumers (i.e. Nototeredo norvagica, Limnoria quadripunctata, Chelura terebrans). Tests were performed with the kruskal.test function from the R package FSA (Ogle et al. 2018). Then, to determine which groups were different from others, post hoc Mann-Whitney tests on each pair of groups were conducted using the pairwise.wilcox.test function from the R package rcompanion (Mangiafico 2019). 


\section{RESULTS}

\subsection{Observations}

All the wood boards were still floating by the end of the experiment. Visible deterioration remained limited to the surface of the wood pieces and was clearly the result of the activity of the gribble, i.e. the isopod Limnoria quadripunctata Holthuis, 1949 and, to a lesser extent, that of the amphipod Chelura terebrans Philippi, 1839. Dismantling of the boards showed that wood could be largely moistened but that the innermost part was still dry. Wood boards harbored on average 2-3 large-size shipworms belonging to the mollusk species Nototeredo norvagica Spengler, 1762. Generally, burrows dug by the shipworms extended to the whole wood board. We do not have information on the temporal evolution of the colonization of the boards. However, amphipods and isopods were pulled out of the wood as they were inside the tunnels and burrows they dug. This observation allowed confidence with respect to the time spent by these colonizers in the aquaria and thus the isotopic balance between the consumers and their sources.

\subsection{Stable isotope compositions of the sources}

The $\delta^{13} \mathrm{C}$ values of the inner dry part of the wood (Fig. 1) ranged from -24.4 to $-24.5 \%$ and the $\delta^{15} \mathrm{~N}$ values ranged from -4.6 to $-2.7 \%$ without any significant change over time. $\mathrm{C} / \mathrm{N}$ ratios were between 550 and 600. The isotope composition of the moistened outer part of the boards differed markedly from that of the inner part (Fig. 1). The parts of the wood in contact with seawater were more depleted in ${ }^{13} \mathrm{C}$ $\left(-27.2\right.$ to $-25.8 \%$ ) and more enriched in ${ }^{15} \mathrm{~N}(-0.4$ to $1.8 \%$ ) than the inner parts (post hoc pairwise Wilcoxon tests, $\mathrm{p}=0.024$ and $\mathrm{p}=0.016$, respectively). The average value of the $\mathrm{C} / \mathrm{N}$ ratios of the soaked parts (mean: 172) also decreased considerably compared to the value of dry wood due to the relative increase in nitrogen content.

$\delta^{13} \mathrm{C}$ and $\delta^{15} \mathrm{~N}$ values of SPOM ranged from -24.8 to $-22.6 \%$ and from 2.4 to $4.8 \%$, respectively. The nitrogen contents of SPOM (C/N ratio: $6.6 \pm 0.4)$ differed from that of wood by 2 orders of magnitude. Overall, the potential food sources were more distinguished based on their nitrogen contents than based on their carbon contents (Kruskal-Wallis $\chi^{2}=9.6429$, $\mathrm{df}=2, \mathrm{p}=0.008055$ and Kruskal-Wallis $\chi^{2}=11.571$, $\mathrm{df}$ $=2, \mathrm{p}=0.001513$, respectively).

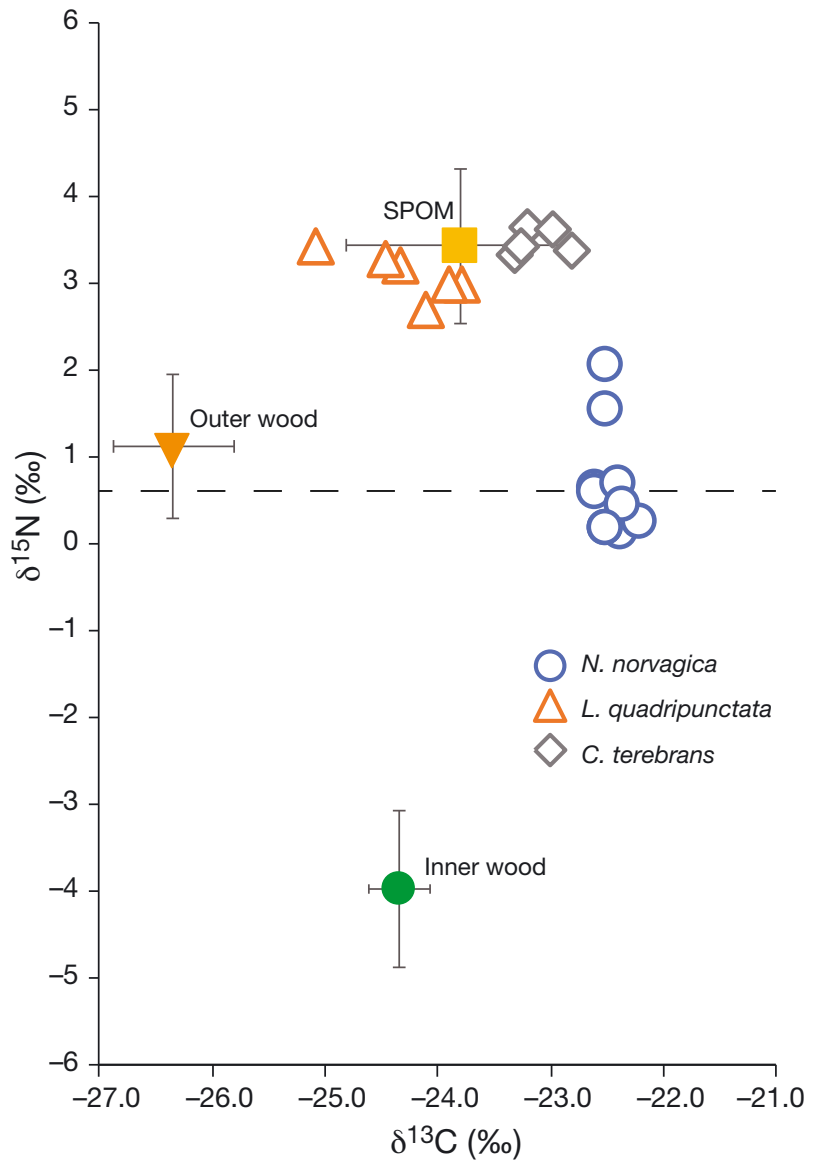

Fig. 1. Carbon and nitrogen isotope compositions of potential food sources (inner wood, outer wood, and suspended particulate organic matter [SPOM]) and consumers (Chelura terebrans, Limnoria quadripunctata, and Nototeredo norvagica). Dashed line: the averaged $\delta^{15} \mathrm{~N}$ value expected for products resulting from the fixation of atmospheric nitrogen. Error bars are SD

\subsection{Stable isotope compositions of the consumers}

Comparisons of $\delta$ values among groups of consumers showed that each species had different carbon and nitrogen isotope compositions (Fig. 1; Kruskal-Wallis $\chi^{2}=15.875$, df $=2, p=0.0003571$ and Kruskal-Wallis $\chi^{2}=14.867$, df $=2, p=0.000591$, respectively). Regarding carbon compositions, shipworms were the most ${ }^{13} \mathrm{C}$-enriched $(-22.8$ to $-22.0 \%$ o), the gribbles the most ${ }^{13} \mathrm{C}$-depleted $(-25.1$ to $-23.8 \%$ ), while the amphipods had intermediate values $\left(-23.3\right.$ to $-22.8 \%$ o). The range of $\delta^{13} \mathrm{C}$ values was wider for L. quadripunctata than for the 2 other species. Regarding the $\delta^{15} \mathrm{~N}$ values, the shipworms were significantly more ${ }^{15} \mathrm{~N}$-depleted than the gribbles and amphipods (post hoc pairwise Wilcoxon tests, $\mathrm{p}=$ 0.00432 , in both cases). $\delta^{15} \mathrm{~N}$ values of $N$. norvagica ( 0.1 to $2.0 \%$ o) also spanned over a wider range than 
that of the crustaceans. The differences between the stable isotopic ratios of wood-borers and wood sources (apparent trophic enrichment factors [TEFs]) were greater than $2 \%$. For both carbon and nitrogen, $\delta$ values of $C$. terebrans were characterized by low variations. The $\mathrm{C} / \mathrm{N}$ ratio (Fig. 2) of the amphipods was systemically lower than that of $N$. norvagica and L. quadripunctata (Kruskal-Wallis $\chi^{2}=10.951$, df $=2$, $\mathrm{p}=0.00418$; post hoc pairwise Wilcoxon tests, $\mathrm{p}=$ 0.0046 and $p=0.0064$, respectively).

\section{DISCUSSION}

Stable isotope compositions were different both within potential food sources and within consumers.

\subsection{Potential food sources}

The wood of the outer edges of the boards was more depleted in ${ }^{13} \mathrm{C}$ than wood from the inner part. As the wood became moistened, the easily useable

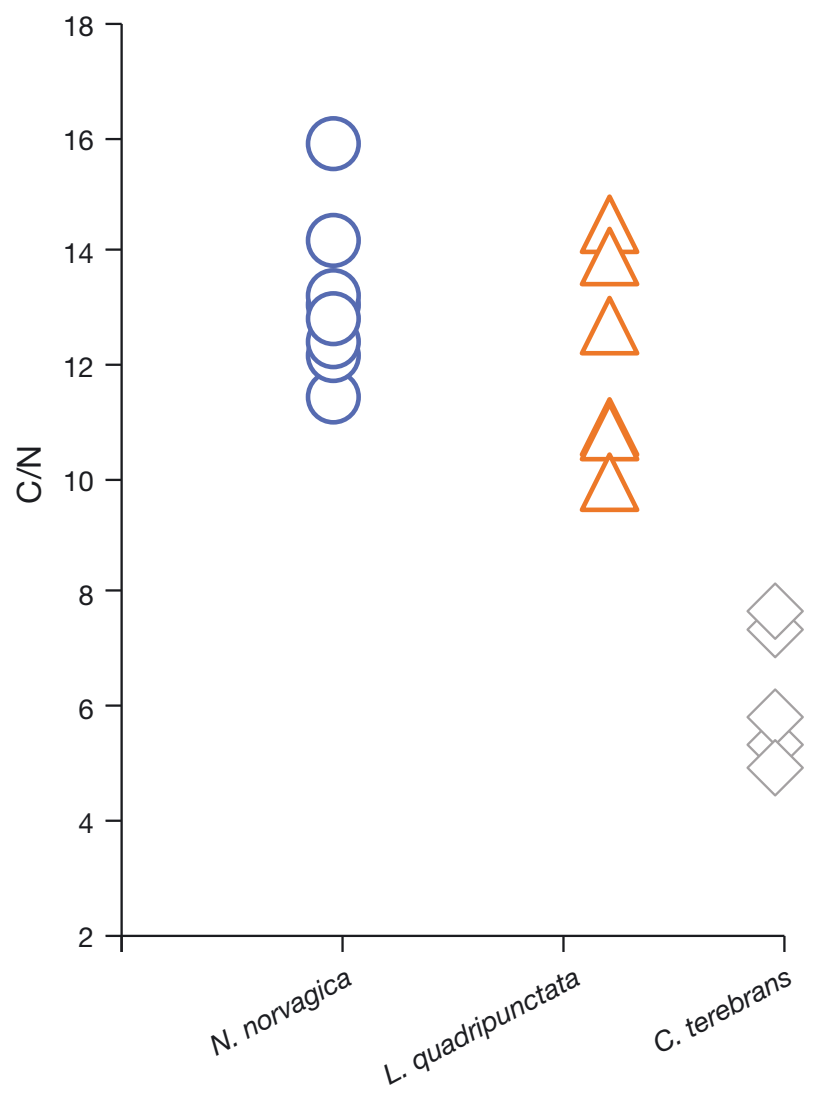

Fig. 2. Carbon to nitrogen ratios of the 3 co-occurring woodborers (Chelura terebrans, Limnoria quadripunctata, and Nototeredo norvagica) polysaccharides were probably preferentially removed and the remaining carbon contents, mainly derived from the more refractory lignin, led to skew the $\delta^{13} \mathrm{C}$ values of wood towards lower values. The fecal pellets of the shipworm, which are notoriously enriched in lignin (Dore \& Miller 1923, Miller \& Boynton 1926, Sabbadin et al. 2018), had a mean $\delta^{13} \mathrm{C}$ value of $-25.5 \%$ (data not shown). During biogeochemical degradation processes, the lignin-derived carbon contents of plant detritus increase, resulting in a decrease of $\delta^{13} \mathrm{C}$ values (Benner et al. 1987). The wood from the outer moistened parts of the boards was considerably enriched in ${ }^{15} \mathrm{~N}$ compared to the inner dry parts. Elemental $\mathrm{C}$ and $\mathrm{N}$ contents were well in the range of those reported in the literature for fresh and decaying wood (Silva et al. 2016, Tramoy et al. 2017). Compared to the dry parts, the total nitrogen content in the moistened parts of the boards increased, decreasing the original ratio of wood by a factor of 3 . These changes are consistent with the development of microbial communities on all parts of the wood in contact with seawater. Populations of marine microorganisms grew by metabolizing wood polysaccharides (Fagervold et al. 2012) and the microbial biomass led to the nitrogen enrichment of the wood parts impregnated with seawater.

Isotope compositions of the SPOM were in accordance with values reported in the literature for the study area in the Mediterranean Sea (Liénart et al. 2017). SPOM was distinct from the wood sources, being more enriched in ${ }^{13} \mathrm{C}$ and ${ }^{15} \mathrm{~N} . \delta^{13} \mathrm{C}$ and $\delta^{15} \mathrm{~N}$ values were variable, reflecting seasonal changes in the composition of the local phytoplankton community (Charles et al. 2005). Because the lighting conditions of the aquaria were not favorable (i.e. low light and most often in total darkness), photosynthetic primary producers cannot be considered a significant food source.

\subsection{Consumers}

\subsubsection{Nototeredo norvagica}

Only 1 of the 4 listed shipworm species in the area of Banyuls (Borges et al. 2014a, Charles et al. 2018a,b) was present in the wood boards. N. norvagica is a broadcast-spawning species with extended planktonic life larvae (Scheltema 1971) allowing the shipworm to colonize the planks through the water pumping circuit of the aquarium. Isotope compositions confirmed that $N$. norvagica relied more on spruce wood than on SPOM for car- 
bon resources and suggested the significant contribution of the nitrogen fixation pathway to the nitrogen contents of the shipworms. The TEF for carbon greatly exceeded the fractionation factor commonly expected between sources and consumers (ca. $0.3 \pm$ $0.21 \%$ according to Caut et al. 2009). Wood is a natural composite in which only polysaccharide constituents are digested by the invertebrates. Thus, $\delta^{13} \mathrm{C}$ values of the mixture of cellulose and hemicellulose from spruce wood can be estimated to be close to $-23 \%$.

The apparent TEF for nitrogen between wood and shipworms deviated greatly from the values reported by Caut et al. (2009) for invertebrate whole bodies $(2.5 \pm 0.25 \%)$. However, given the very low nitrogen content of wood, xylophages must cover their needs by other routes. Isotope data clearly demonstrate that the contribution of SPOM as a food source to shipworms is only incidental. Nitrogen in N. norvagica therefore likely came from the endosymbiotic relationship between the shipworms and nitrogen-fixing bacteria hosted in their gills (Waterbury et al. 1983, Lechene et al. 2007). In Bankia carinata, nitrogen-fixing endosymbionts supply most of the nitrogen (Charles et al. 2018a). Our results suggest that this is also the case for N. norvagica, given that (1) the $\delta^{15} \mathrm{~N}$ value for dissolved marine $\mathrm{N}_{2}$ is about $0.6 \%$ (Sigman et al. 2009), (2) the fractionation factor between $\mathrm{N}_{2}$ and the diazotrophs is small (Sigman et al. 2009), and (3) the fractionation factor between $\mathrm{N}_{2}$-fixing symbionts and their host is close to 0 (Conway et al. 1989). Otherwise, the total nitrogen contents of $N$. norvagica was very low, suggesting a dietary nitrogen deficiency. The buoyancy status of the wood as well as the resource exhaustion necessarily have an influence on the nitrogen isotope composition of the shipworms (Table 1). In case of deficiency, the animals adopt an opportunistic behavior towards the sources of nitrogen that may explain the discrepancies between species (Paalvast \& van der Velde 2013) and between studies (Nishimoto et al. 2009). Paalvast

Table 1. Comparison of nitrogen stable isotope $( \pm \mathrm{SD})$ values of shipworms from different wood gathered at sea

\begin{tabular}{|lccl|}
\hline Shipworm species & $\delta^{15} \mathrm{~N}(\%)$ & Tree species & Study \\
\hline Teredo sp. cf. T. clappi & 4.1 & Unknown & Nishimoto et al. (2009) \\
Teredothyra smithi & $4.1 \pm 0.3$ & Unknown & Nishimoto et al. (2009) \\
Bankia carinata & $4.0 \pm 0.2$ & Unknown & Nishimoto et al. (2009) \\
Teredo navalis & $7.4 \pm 0.3$ & Picea abies & Paalvast \& van der \\
& & & Velde (2013) \\
B. carinata & $0.5 \pm 0.4$ & Alnus glutinosa & Charles et al. (2018b) \\
N. norvagica & $0.6 \pm 0.6$ & P. abies & Present study \\
\hline
\end{tabular}

\& van der Velde (2013) concluded that Teredo navalis derived most of their food from SPOM rather than from the spruce wood they bored. Nishimoto et al. (2009) suggested that the major food source of wood-boring bivalves, including $B$. carinata, was the symbiotic bacteria, but that the shipworms probably selectively used cellulose as their main carbon source. In our study, 2 shipworm individuals had higher ${ }^{15} \mathrm{~N}$ contents than the others (Fig. 1); this could reflect that they dug the moistened part of the boards and ingested wood-degrading bacteria leading to an increase in their $\delta^{15} \mathrm{~N}$ values.

\subsubsection{Limnoria quadripunctata}

The nitrogen content in L. quadripunctata was fairly low, and their $\delta^{15} \mathrm{~N}$ values were higher and less variable than in the shipworms. $\delta^{13} \mathrm{C}$ values highlight that the isopods rely on the carbon of the wood parts soaked with seawater. Devoid of gut-resident microbiota (Boyle \& Mitchell 1978, Sleeter et al. 1978) and without an endosymbiotic relationship, the isopods must supplement their diet to get the nitrogen they need by ingesting the microbes that creep into and grow on the wood (Cragg et al. 1999), leading to higher $\delta^{15} \mathrm{~N}$ values compared to shipworms. Hemocyanin facilitation of cellulose digestion by the gribble has been experimentally demonstrated (Besser et al. 2018); nevertheless, carbon isotope composition of Limnoria deviated from that of Nototeredo, which is very likely related to the lower $\delta^{13} \mathrm{C}$ values of the food resources they rely on (i.e. outer moistened wood). Four main reasons can be invoked to explain this discrepancy: (1) differences in the diet composition, i.e Limnoria rely on the microbial community developing on the wood while Nototeredo are able to feed directly on the wood; (2) differences in the composition of the main carbon source as the $\delta^{13} \mathrm{C}$ value of wood was indeed altered by seawater soaking; (3) differences in the ability to alter lignin impermeability (Table 2), i.e. the phenoloxidase activity of hemocyanin (a respiratory protein) in limnoriids (King et al. 2010) disrupts the association between lignin and polysaccharide fractions, whereas this is probably accomplished by auxiliary activity families (AAs) and LPMOs in shipworms (Levasseur et al. 2013, Sabbadin et al. 2018); and (4) differences in the ability to depolymerize the polysaccharides of wood (Table 2), i.e. unlike 
Table 2. Comparison of lignocellulolytic enzyme equipment from the 3 taxonomic groups. AA: auxiliary activity enzyme; CAZyme: carbohydrate active enzyme; CE: carbohydrate esterase; GH: glycoside hydrolase enzyme (Values are from the CAZymes database. Each enzyme family or subfamily has its own number); LPMO: lytic polysaccharide monooxygenase enzyme

\begin{tabular}{|c|c|c|c|c|c|c|}
\hline \multirow[t]{2}{*}{ Wood-borers } & \multirow[t]{2}{*}{ Origin } & \multirow{2}{*}{$\begin{array}{l}\text { Phenoloxidase } \\
\text { activity }\end{array}$} & \multirow{2}{*}{$\begin{array}{l}\text { LPMOs } \\
\text { activity }\end{array}$} & \multicolumn{2}{|c|}{ — CAZymes families } & \multirow[t]{2}{*}{ References } \\
\hline & & & & GHs & CEs & \\
\hline Crustaceans & Endogenous & Hemocyanin & $\begin{array}{l}\text { Seawater } \\
\text { salts }\end{array}$ & $7,5,9,30,35$ & & $\begin{array}{l}\text { King et al. (2010), } \\
\text { Kern et al. (2013), } \\
\text { Cragg et al. (2015), } \\
\text { Besser et al. (2018) }\end{array}$ \\
\hline \multirow[t]{2}{*}{ Bivalves } & & $\mathrm{AA}$ & AA10 & $6,11,5,10,9,115$ & $3,15,4$ & $\begin{array}{l}\text { O'Connor et al. (2014), } \\
\text { Sabbadin et al. (2018) }\end{array}$ \\
\hline & Endogenous & & & $\begin{array}{c}9,45,1,13,2,18,31 \\
5,10,38,30,20,35 \\
22,84\end{array}$ & & Sabbadin et al. (2018) \\
\hline
\end{tabular}

shipworms, Limnoria lack LPMOs but salts from seawater may act instead (Besser et al. 2018). Arthropods also have a collection of carbohydrate active enzymes which is smaller than that of the mollusk, and are unable to hydrolyze hemicelluloses. What is intriguing here is that the gribbles were very depleted in ${ }^{13} \mathrm{C}$, and some more particularly, compared to shipworms (Fig. 1). It is likely, as suggested in the literature (Cragg et al. 1999), that gribbles benefit from the conditioning of lignin by marine fungi (Pointing \& Hyde 2000). Consumption of the fungi or compounds released by the fungi could explain the fairly low $\delta^{13} \mathrm{C}$ values of Limnoria. As the $\delta^{13} \mathrm{C}$ value of early wood differs from that of late wood (Hill et al. 1995) and lignin to sugar polymer ratios differ (Loader et al. 2003), if limnoriids preferentially dig tunnels in early wood, this could also affect their isotope signatures.

\subsubsection{Chelura terebrans}

Both arthropods coexisted, but amphipods were more enriched in ${ }^{13} \mathrm{C}$ and ${ }^{15} \mathrm{~N}$ compared to isopods. The ranges of the $\delta$ values were also narrower and the $\mathrm{C} / \mathrm{N}$ ratio significantly lower in Chelura than in Limnoria and Nototeredo. This suggests that tissue turnover rates were faster and/or that the carbon sources were different and/or less variable. C. terebrans lives inside the galleries of Limnoria and feeds on limnoriid fecal pellets (Boyle \& Mitchell 1978). The $\delta^{15} \mathrm{~N}$ values of the amphipod and of Limnoria was about $2 \%$ higher than that of dissolved $\mathrm{N}_{2}$. Surfaces in Limnoria burrows are colonized by bacteria and other microbes (Sleeter et al. 1978). Marine microbial communities developing on softwood are characterized by large proportions of Alphaproteobacteria, Gammaproteobacteria and Planctomycetes (Fagervold et al. 2014), and most of them are capable of $\mathrm{N}_{2}$ fixation (Delmont et al. 2018). Preliminary molecular investigations failed to recover a detectable quantity of bacterial DNA on our wood samples. Scanning electron microscopy (SEM) confirmed the absence of bacteria in the dry inner part of the wood pieces, and their low abundance on the outer edge of the boards but rather the presence of hyphae of fungi (Fig. A1 in the appendix). SEM observations of the exoskeletons also indicated that the isopod was covered with ciliates, fungal hyphae, bacteria, and microphyte remains. Even though limnoriids can colonize freshly exposed wood with negligible microbial colonization (Borges et al. 2009), Daniel et al. (1991) have shown that, under natural conditions, L. lignorum can ingest bacterial- and fungal-degraded wood. Björdal \& Nilsson (2008) showed that soft rot fungi and tunnelling bacteria were the main wood microbial degraders above the sea bed. In this case, decay starts in the surface layer of the wood, and proceeds inwards. Limnoriids may also gain nitrogen by grooming of their exoskeleton (Delgery et al. 2006). In contrast, amphipods appeared free of epibionts (Fig. A1), suggesting the existence of biotic interactions specific to each of these crustaceans. Nevertheless, it is likely that amphipods, isopods, and eventually shipworms partly feed on fungi and bacteria that grow on wood. The dependency on this source is certainly greater for amphipods than for isopods because the nitrogen requirement of the amphipod is higher and the colonization of the wood usually occurs after the installation of the isopod. Nitrogen limitation of the arthropods, however, could call for specific adaptations, including a limitation of excretion and recycling of nitrogen 
waste. Such a strategy leads to a ${ }^{15} \mathrm{~N}$ enrichment. In a study of the effect of starvation, Doi et al. (2017) showed that $\delta^{15} \mathrm{~N}$ values shift from -0.82 to $4.30 \%$ (mean: $0.47 \%$ ) in starved animals and that their location in that range depended on excretion strategies.

\section{CONCLUSION}

The isotope compositions of driftwood evolve with the duration of exposure to seawater, and the microorganisms that cause these changes can become a part of the diet of the wood-eaters. Depending on the speed at which they colonize driftwood and on their drilling capabilities, wood-borers face a food source which is more or less diluted or better nutritionally balanced. Shipworms, through their endosymbiosis with nitrogen-fixing bacteria, are the only ones able to colonize the wood when it is still practically dry. Gribbles drill the superficial soaked parts, and their nitrogen needs are low. The settlement of teredinids and the colonization by limnoriids do not necessarily require colonization by bacteria and fungi beforehand. In contrast, the amphipods Chelura terebrans colonize pieces of wood when these have been long enough in the water to allow the establishment of dense epibiota that include the isopod. The ability to digest cellulose is different between taxonomic groups and depends on symbioses and on the extent of the enzymatic arsenal available to hydrolyze the wood components. Within wood-boring species, nitrogen and carbon sources can be completely distinct from one another, a situation that differs profoundly from usual models that consider that $\mathrm{C}$ and $\mathrm{N}$ elements are derived from the same food source.

Acknowledgements. We thank Fabien Aubert for the preparation of the samples and Gaël Guillou for stable isotope analysis. We are grateful to Joseph Garrigue and JeanAndré Magdalou, curators of the Réserve Naturelle Nationale de la Forêt de la Massane, for sharing their expert knowledge on wood and forestry. This work was supported by the EC2CO (Écosphère Continentale et Côtière) national program of the CNRS-INSU, as part of the DRIL (Dynamique et Réactivité des Interfaces Littorales) topics, under the title: De la forêt à la mer: Transfert et recyclage du bois mort sur la marge continentale méditerranéenne 2016-2017.

\section{LITERATURE CITED}

Barnard JL (1955) The wood-boring habits of Chelura terebrans Philippi in Los Angeles Harbor. Essays in the natural sciences in honor of Capt Allan Hancock. Allan Hancock Foundation, University of Southern California, LA, p 87-98
Barnard JL (1959) Generic partition in the amphipod family Cheluridae, marine wood borers. Pac Nat 1:3-12

Bellan-Santini D, Karaman G, Krapp-Schickel G, Ledoyer M, Myers A, Ruffo S, Schiecke U (1982) The Amphipoda of the Mediterranean. Part 1: Gammaridae (Acanthonotozomatidae to Gammaridae). Mémoires de l'Institut océanographique. Monaco Institut Océanographique, Monaco

* Benner R, Fogel ML, Sprague EK, Hodson RE (1987) Depletion of ${ }^{13} \mathrm{C}$ in lignin and its implications for stable carbon isotope studies. Nature 329:708-710

* Benner R, Fogel ML, Sprague EK (1991) Diagenesis of belowground biomass of Spartina alterniflora in saltmarsh sediments. Limnol Oceanogr 36:1358-1374

Besser K, Malyon GP, Eborall WS, Paro da Cunha G and others (2018) Hemocyanin facilitates lignocellulose digestion by wood-boring marine crustaceans. Nat Commun 9:5125

Betcher MA, Fung JM, Han AW, O'Connor R and others (2012) Microbial distribution and abundance in the digestive system of five shipworm species (Bivalvia: Teredinidae). PLOS ONE 7:e45309

* Björdal CG, Nilsson T (2008) Reburial of shipwrecks in marine sediments: a long-term study on wood degradation. J Archaeol Sci 35:862-872

Borges LMS, Costa FO (2014) New records of marine wood borers (Bivalvia: Teredinidae and Isopoda: Limnoriidae) from São Miguel, Azores, with a discussion of some aspects of their biogeography. Açoreana 10:109-116

Borges LMS, Cragg SM, Busch S (2009) A laboratory assay for measuring feeding and mortality of the marine woodborer Limnoria under forced feeding conditions: a basis for a standard test method. Int Biodeterior Biodegrad 63: 289-296

*Borges LMS, Merckelbach LM, Sampaio Í, Cragg SM (2014a) Diversity, environmental requirements, and biogeography of bivalve wood-borers (Teredinidae) in European coastal waters. Front Zool 11:13

*Borges LMS, Merckelbach LM, Cragg SM (2014b) Biogeography of wood-boring crustaceans (Isopoda: Limnoriidae) established in European coastal waters. PLOS ONE 9:e109593

Boyle PJ, Mitchell R (1978) Absence of microorganisms in crustacean digestive tracts. Science 200:1157-1159

* Bredon M, Herran B, Lheraud B, Bertaux J, Grève $P$, Moumen B, Bouchon D (2019) Lignocellulose degradation in isopods: new insights into the adaptation to terrestrial life. BMC Genomics 20:462

*Bunn SE, Loneragan NR, Kempster MA (1995) Effects of acid washing on stable isotope ratios of $\mathrm{C}$ and $\mathrm{N}$ in penaeid shrimp and seagrass: implications for food-web studies using multiple stable isotopes. Limnol Oceanogr 40:622-625

* Castelló J (2011) The genus Limnoria (Limnoriidae, Isopoda, Crustacea) in Europe, including a key to species. Zootaxa 2968:1-25

* Caut S, Angulo E, Courchamp F (2009) Variation in discrimination factors $\left(\delta^{15} \mathrm{~N}\right.$ and $\left.\delta^{13} \mathrm{C}\right)$ : the effect of diet isotopic values and applications for diet reconstruction. J Appl Ecol 46:443-453

* Charles F, Lantoine F, Brugel S, Chretiennot-Dinet M, Quiroga I, Riviere A (2005) Seasonal survey of the phytoplankton biomass, composition and production in a littoral NW Mediterranean site, with special emphasis on the picoplanktonic contribution. Estuar Coast Shelf Sci 65:199-212 
Charles F, Sauriau PG, Aubert F, Lebreton B, Lantoine F, Riera P (2018a) Sources partitioning in the diet of the shipworm Bankia carinata (J.E. Gray, 1827): an experimental study based on stable isotopes. Mar Environ Res 142:208-213

Charles F, Coston-Guarini J, Guarini JM, Lantoine F (2018b) It's what's inside that counts: computer-aided tomography for evaluating the rate and extent of wood consumption by shipworms. J Wood Sci 64:427-435

Chen H (ed) (2014) Chemical composition and structure of natural lignocellulose. In: Biotechnology of lignocellulose. Springer, Dordrecht, p 25-71

* Coll PM, Fernandez-Abalos JM, Villanueva JR, Santamaria R, Perez P (1993) Purification and characterization of a phenoloxidase (laccase) from the lignin-degrading basidiomycete PM1 (CECT 2971). Appl Environ Microbiol 59:2607-2613

* Conway N, Capuzzo JM, Fry B (1989) The role of endosymbiotic bacteria in the nutrition of Solemya velum: evidence from a stable isotope analysis of endosymbionts and host. Limnol Oceanogr 34:249-255

* Cookson LJ, Cragg SM, Hendy IW (2012) Wood-boring limnoriids (Crustacea, Isopoda) including a new species from mangrove forests of the Tukang Besi Archipelago, Indonesia. Zootaxa 3248:25-34

Cragg SM, Pitman AJ, Henderson SM (1999) Developments in the understanding of the biology of marine wood boring crustaceans and in methods of controlling them. Int Biodeterior Biodegrad 43:197-205

Cragg SM, Jumel MC, Al-Horani FA, Hendy IW (2009) The life history characteristics of the wood-boring bivalve Teredo bartschi are suited to the elevated salinity, oligotrophic circulation in the Gulf of Aqaba, Red Sea. J Exp Mar Biol Ecol 375:99-105

* Cragg SM, Beckham GT, Bruce NC, Bugg TD and others (2015) Lignocellulose degradation mechanisms across the Tree of Life. Curr Opin Chem Biol 29:108-119

* Daniel G, Cragg SM, Nilsson T (1991) Limnoria lignorum ingests bacterially and fungally decayed wood. Holz Roh- Werkst 49:488-490

Delgery CC, Cragg SM, Busch S, Morgan E (2006) Effects of the epibiotic heterotrich ciliate Mirofolliculina limnoriae and of moulting on faecal pellet production by the woodboring isopods Limnoria tripunctata and L. quadripunctata. J Exp Mar Biol Ecol 334:165-173

Delmont TO, Quince C, Shaiber A, Esen ÖC and others (2018) Nitrogen-fixing populations of Planctomycetes and Proteobacteria are abundant in surface ocean metagenomes. Nat Microbiol 3:804-813

Welwiche CC, Zinke PJ, Johnson CM, Virginia RA (1979) Nitrogen isotope distribution as a presumptive indicator of nitrogen fixation. Bot Gaz 140:S65-S69

* Distel DL, Altamia MA, Lin Z, Shipway JR and others (2017) Discovery of chemoautotrophic symbiosis in the giant shipworm Kuphus polythalamia (Bivalvia: Teredinidae) extends wooden-steps theory. Proc Natl Acad Sci USA 114:E3652-E3658

* Doi H, Akamatsu F, González AL (2017) Starvation effects on nitrogen and carbon stable isotopes of animals: an insight from meta-analysis of fasting experiments. R Soc Open Sci 4:170633

Dore WH, Miller RC (1923) The digestion of wood by Teredo navalis. Univ Calif Publ Zool 22:384-400

Eibinger M, Ganner T, Bubner P, Rošker S and others (2014) Cellulose surface degradation by a lytic polysaccharide monooxygenase and its effect on cellulase hydrolytic efficiency. J Biol Chem 289:35929-35938

*Fagervold SK, Galand PE, Zbinden M, Gaill F, Lebaron P, Palacios C (2012) Sunken woods on the ocean floor provide diverse specialized habitats for microorganisms. FEMS Microbiol Ecol 82:616-628

* Fagervold SK, Romano C, Kalenitchenko D, Borowski C, Nunes-Jorge A, Martin D, Galand PE (2014) Microbial communities in sunken wood are structured by woodboring bivalves and location in a submarine canyon. PLOS ONE 9:e96248

*Heise EA, Raymond A, Parsons-Hubbard K, Walker SE and others (2011) Wood taphonomy in a tropical marine carbonate environment: experimental results from Lee Stocking Island, Bahamas. Palaeogeogr Palaeoclimatol Palaeoecol 312:363-379

*Hill SA, Waterhouse JS, Field EM, Switsur VR, Rees TA (1995) Rapid recycling of triose phosphates in oak stem tissue. Plant Cell Environ 18:931-936

* Janusz G, Pawlik A, Sulej J, Świderska-Burek U, JaroszWilkołazka A, Paszczyński A (2017) Lignin degradation: microorganisms, enzymes involved, genomes analysis and evolution. FEMS Microbiol Rev 41: 941-962

K Kennedy P, Kennedy H, Papadimitriou S (2005) The effect of acidification on the determination of organic carbon, total nitrogen and their stable isotopic composition in algae and marine sediment. Rapid Commun Mass Spectrom 19:1063-1068

Kern M, McGeehan JE, Streeter SD, Martin RNA and others (2013) Structural characterization of a unique marine animal family 7 cellobiohydrolase suggests a mechanism of cellulase salt tolerance. Proc Natl Acad Sci USA 110: 10189-10194

*King AJ, Cragg SM, Li Y, Dymond J and others (2010) Molecular insight into lignocellulose digestion by a marine isopod in the absence of gut microbes. Proc Natl Acad Sci USA 107:5345-5350

Lamlom SH, Savidge RA (2003) A reassessment of carbon content in wood: variation within and between 41 North American species. Biomass Bioenergy 25:381-388

* Lechene CP, Luyten Y, McMahon G, Distel DL (2007) Quantitative imaging of nitrogen fixation by individual bacteria within animal cells. Science 317:1563-1566

* Levasseur A, Drula E, Lombard V, Coutinho PM, Henrissat B (2013) Expansion of the enzymatic repertoire of the CAZy database to integrate auxiliary redox enzymes. Biotechnol Biofuels 6:41

* Liénart C, Savoye N, Bozec Y, Breton E and others (2017) Dynamics of particulate organic matter composition in coastal systems: a spatio-temporal study at multi-systems scale. Prog Oceanogr 156:221-239

*Loader NJ, Robertson I, McCarroll D (2003) Comparison of stable carbon isotope ratios in the whole wood, cellulose and lignin of oak tree rings. Palaeogeogr Palaeoclimatol Palaeoecol 196:395-407

* MacIntosh H, de Nys R, Whalan S (2012) Shipworms as a model for competition and coexistence in specialized habitats. Mar Ecol Prog Ser 461:95-105

*Malet N, Sauriau PG, Ryckaert M, Malestroit P, Guillou G (2008) Dynamics and sources of suspended particulate organic matter in the Marennes-Oléron oyster farming bay: insights from stable isotopes and microalgae ecology. Estuar Coast Shelf Sci 78:576-586

Mangiafico S (2019) rcompanion: functions to support exten- 
sion education program evaluation. $\mathrm{R}$ package version 2.0.10. https://cran.r-project.org/package=rcompanion

Menzies RJ (1952) A new species of Limnoria (Crustacea: Isopoda) from Southern California. Bull South Calif Acad Sci 50:86-88

Miller RC, Boynton LC (1926) Digestion of wood by the shipworm. Science 63:524

Nishimoto A, Mito S, Shirayama Y (2009) Organic carbon and nitrogen source of sunken wood communities on continental shelves around Japan inferred from stable isotope ratios. Deep Sea Res II 56:1683-1688

Nishimoto A, Haga T, Asakura A, Shirayama Y (2015) An experimental approach for understanding the process of wood fragmentation by marine wood borers in shallow temperate waters. Mar Ecol Prog Ser 538:53-65

O'Connor RM, Fung JM, Sharp KH, Benner JS and others (2014) Gill bacteria enable a novel digestive strategy in a wood-feeding mollusk. Proc Natl Acad Sci USA 111: E5096-E5104

Ogle DH, Wheeler P, Dinno A (2018) FSA: fisheries stock analysis. $\mathrm{R}$ package version 0.8.22. https://cran.r-project.org/package $=$ FSA

Paalvast P, van der Velde G (2013) What is the main food source of the shipworm (Teredo navalis)? A stable isotope approach. J Sea Res 80:58-60

Pointing SB, Hyde KD (2000) Lignocellulose degrading marine fungi. Biofouling 15:221-229

R Core Team (2018) R: a language and environment for statistical computing. R Foundation for Statistical Computing, Vienna. www.r-project.org

Sabbadin F, Pesante G, Elias L, Besser K and others (2018) Uncovering the molecular mechanisms of lignocellulose digestion in shipworms. Biotechnol Biofuels 11:59

Scheltema RS (1971) Dispersal of phytoplanktotrophic shipworm larvae (Bivalvia: Teredinidae) over long distances by ocean currents. Mar Biol 11:5-11

Sigman DM, Karsh KL, Casciotti KL (2009) Ocean process tracers: nitrogen isotopes in the ocean. In: Encyclopedia of ocean sciences. Elsevier, Amsterdam, p 4138-4153

Silva LCR, Sun G, Zhu-Barker X, Liang Q, Wu N, Horwath WR (2016) Tree growth acceleration and expansion of alpine forests: the synergistic effect of atmospheric and edaphic change. Sci Adv 2:e1501302

Sinsabaugh RL (2010) Phenol oxidase, peroxidase and organic matter dynamics of soil. Soil Biol Biochem 42: 391-404

Sleeter TD, Boyle PJ, Cundell AM, Mitchell R (1978) Relationships between marine microorganisms and the wood-boring isopod Limnoria tripunctata. Mar Biol 45: 329-336

Søreide JE, Tamelander T, Hop H, Hobson KA, Johansen I (2006) Sample preparation effects on stable C and N isotope values: a comparison of methods in Arctic marine food web studies. Mar Ecol Prog Ser 328:17-28

* Terrett OM, Dupree P (2019) Covalent interactions between lignin and hemicelluloses in plant secondary cell walls. Curr Opin Biotechnol 56:97-104

* Tramoy R, Sebilo M, Nguyen Tu TT, Schnyder J (2017) Carbon and nitrogen dynamics in decaying wood: paleoenvironmental implications. Environ Chem 14:9

Turner RD (1966) A survey and illustrated catalogue of the Teredinidae (Mollusca, Bivalvia). Museum of Comparative Zoology, Harvard University, Cambridge, MA

Vaaje-Kolstad G, Westereng B, Horn SJ, Liu Z, Zhai H, Sørlie M, Eijsink VGH (2010) An oxidative enzyme boosting the enzymatic conversion of recalcitrant polysaccharides. Science 330:219-222

*Velásquez M, Shipway JR (2018) A new genus and species of deep-sea wood-boring shipworm (Bivalvia: Teredinidae) Nivanteredo coronata n. sp. from the Southwest Pacific. Mar Biol Res 14:806-815

Waterbury JB, Calloway CB, Turner RD (1983) A cellulolytic nitrogen-fixing bacterium cultured from the gland of Deshayes in shipworms (Bivalvia: Teredinidae). Science 221:1401-1403

* Westereng B, Cannella D, Wittrup Agger J, Jørgensen H, Larsen Andersen M, Eijsink VGH, Felby C (2015) Enzymatic cellulose oxidation is linked to lignin by longrange electron transfer. Sci Rep 5:18561

* Yücel M, Galand PE, Fagervold SK, Contreira-Pereira L, Le Bris NL (2013) Sulfide production and consumption in degrading wood in the marine environment. Chemosphere 90:403-409 
Appendix.
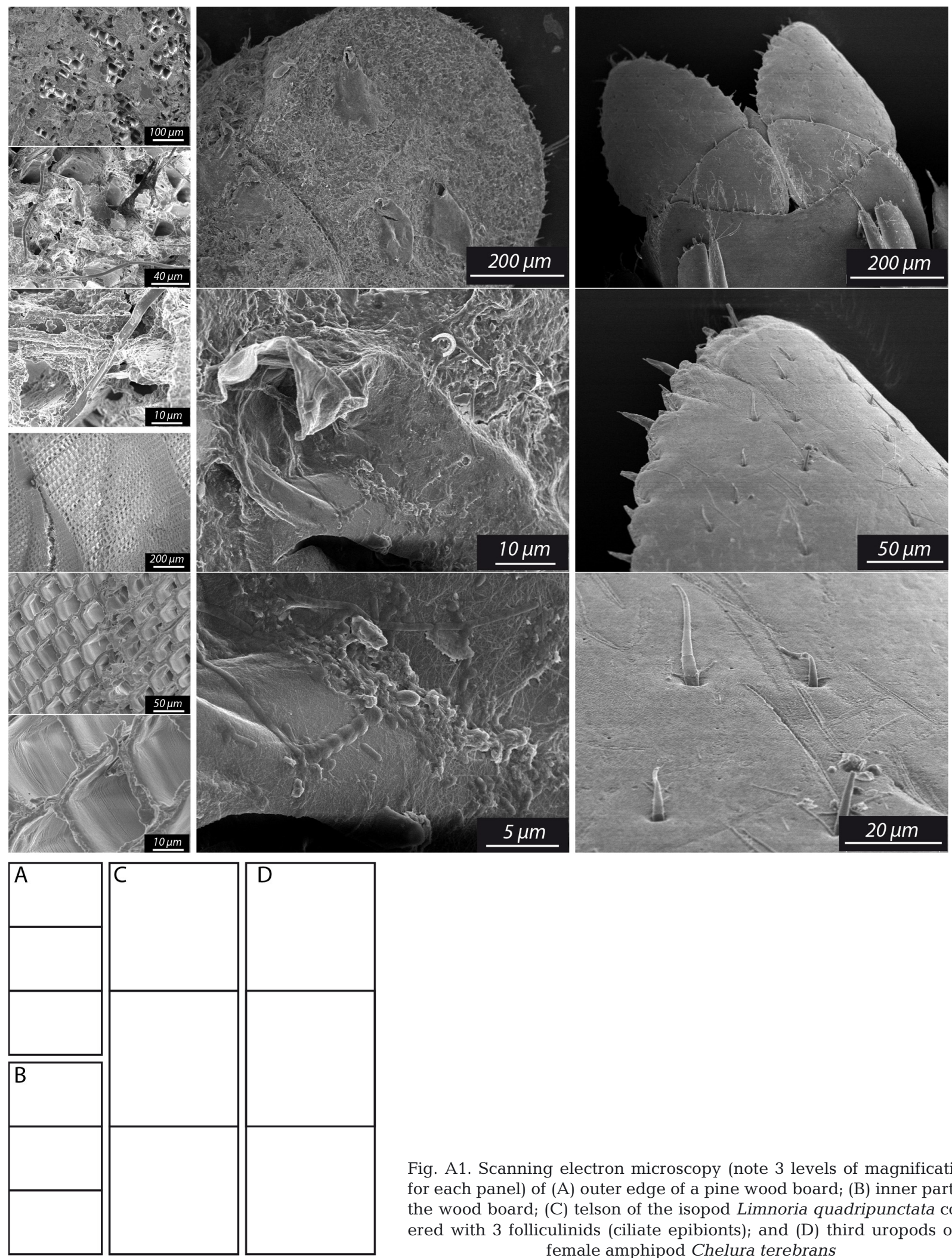

Fig. A1. Scanning electron microscopy (note 3 levels of magnification for each panel) of (A) outer edge of a pine wood board; (B) inner part of the wood board; (C) telson of the isopod Limnoria quadripunctata covered with 3 folliculinids (ciliate epibionts); and (D) third uropods of a female amphipod Chelura terebrans

Editorial responsibility: Anna Metaxas, Halifax, Nova Scotia, Canada
Submitted: June 12, 2019; Accepted: December 4, 2019 Proofs received from author(s): February 14, 2020 